\title{
INNOVATION COMPONENT OF POLYSTRUCTURAL PROCESS OF FORMATION AND DIAGNOSTICS OF ECONOMIC SECURITY OF ENTERPRISE
}

\author{
А. С. Степанов, \\ здобувач, Міжнародний університет бізнесу і права, м. Херсон
}

\author{
ІННОВАЦІЙНА СКАААОВА ПОАІСТРУКТУРНОГО ПРОЦЕСУ ФОРМУВАННЯ \\ ТА АІАГНОСТИКИ ЕКОНОМІЧНОЇ БЕЗПЕКИ ПІАПРИЄМСТВА
}

For the first time, the use of the $V \& V$ concept for the diagnosis of economic security of agricultural enterprises was proposed. This study creates regulatory models for enterprises to make the best decisions in the network of values, when the goal is an efficient and structurally reliable cooperation. The models use theoretical game concepts for multilateral decision making, which involves both cooperation and competition.

The purpose of the article was to identify the innovative component of the polystructural process of forming and diagnosing economic security of the enterprise. From a conceptual point of view, it is useful to distinguish between the analysis and diagnostics of the system of economic security of an individual enterprise, from the analysis of economic security of a set of enterprises with clear group characteristics or models. Each individual enterprise or set of enterprises has its own peculiarities that arise as a result of changes in resources and circumstances in the context of local institutions and policies. They turn into productive activities, as well as enterprise consumption and decision-making activities. In this analysis, the system of economic security of a set of enterprises is defined as a combination of small and large enterprises, which, like a group, have similar patterns of life and consumption, as well as constraints and opportunities, and for which such development strategies and interventions would be appropriate. Often such systems have similar agroecological and market conditions.

Enterprises usually make their decisions to maximize profits. Profit is the result of incoming and outgoing cash flows, which, on the one hand, depend on the success of the market, and, for example, on operating costs and capital costs, on the other. Consequently, future cash flows determine the level of success, as long as the cost of time is recorded. However, an accurate estimate of future cash flows at the time of the decision is usually unrealistic. Uncertainty, for example, the development of the market, the decisions of competitors, as well as future costs, give rise to high uncertainty in future cash flows.

Вперше запропоновано використання $V \& V$ концепції при діагностиці економічної безпеки сільськогосподарських підприємств. Це дослідження створює нормативні моделі Аля піАприємств Аля прийняття кращих рішень у мережі цінностей, коли метою є ефективне та структурно надійне співробітництво. Моделі використовують теоретико-ігрові концепції Аля багатостороннього прийняття рішень, що передбачає як співпрацю так і конкуренцію. Метою статті стало визначення інноваційної складової поліструктурного процесу формування та діагностики економічної безпеки підприємства. 3 концептуальної точки зору, корисно розрізняти аналіз та Аіагностику системи економічної безпеки окремого підприємства, від аналізу економічної безпеки сукупності підприємств зі зрозумілими груповими характеристиками або моделями. Кожне окреме підприємство або сукупність підприємств має свої специфічні особливості, що виникають внаслідок змін ресурсів та обставин у контексті місцевих інституцій та політики. Вони перетворюються на виробничу діяльність, а також на споживання підприємств та діяльність 3 прийняття рішень. 
У цьому аналізі система економічної безпеки сукупності підприємств визначається як поєАнання малих і великих підприємств, які, як група, мають подібні структури життєАіяльності та споживання, а також обмеження та мождивості, і Аля яких подібні стратегії розвитку і втручання були б доречними. Часто такі системи мають подібні агроекологічні та ринкові умови.

Підприємства зазвичай приймають свої рішення, щоб максимізувати прибуток. Прибуток є результатом вхідних та вихідних грошових потоків, які, з одного боку, залежать віА успішності ринку, i, наприклаА, віА операційних витрат, та капітальних витрати - 3 іншого. Отже, майбутні грошові потоки визначають рівень успішності до того часу поки обліковується вартість часу. ОАнак точна оцінка майбутніх грошових потоків на момент прийняття рішення $\epsilon$ зазвичай нереальною; невизначеності, наприклаА, розвиток ринку, рішення конкурентів, і навіть майбутні витрати Аають високу невизначеність у майбутніх грошових потоках.

Key words: economic security, innovation, conception, model, agricultural enterprise.

Ключові слова: економічна безпека підприємства, інновачій, конщепчія, модель, сільськогосподарське підприємство.

\section{PROBLEM STATEMENT IN GENERAL FORM}

The process of managing and diagnosing economic security of an enterprise is rather complex and multifaceted, as it includes an analysis of the theoretical aspects of ensuring economic security of an economic entity, the definition of methodological foundations for maintaining a high level of economic security, an analysis of the economic security of an enterprise on its functional components. As part of our study, the company's economic security is defined as the state of corporate resources and business opportunities, which guarantees the most effective use of them for the stable functioning and dynamic scientifictechnical and social development of the enterprise, prevention of internal and external negative influences (threats).

The main objective of the company's economic security is to ensure its stable and efficient operation and high potential for future development.

\section{ANALYSIS OF RECENT RESEARCH AND PUBLICATIONS}

The problem of diagnosing economic security at an enterprise is very relevant and is considered by many scholars, including: Berezin O. V., Vasilenko V.P., Ivanilov O.S., Ivanyuta T.M. and other. The issues of studying the content and essence of the innovation security of the enterprise are Krasnoshchokova Yu.V., Maksimova T.S., Filimonova O.V., Lyshtvan K.V., Magydov Ye.G. etc.
For example, Nataliya Pedchenko, Victoria Strilec, Galina M. Kolisnyk, Mariia V. Dykha and Serhiy Frolov (2018) write that access to finance is one of the key issues for small business entities in the process of their creation, existence and development. The study of the current state of small business in Ukraine points to financial difficulties at the initial stages of the life cycle, which determine the need to increase the value of alternative sources of external financing and provide an instrument for governments and other stakeholders to understand the financing needs of enterprises.

Ganna Blakyta, Natalia Guliaeva, Iryna Vavdijchyk, Olena Matusova and Anastasia Kasianova (2018) note that currently the Ukrainian economy is developing through the regular influence of accelerating economic relations at all levels. In addition, the interaction of business entities faces increasing pressures of change in the social, political and environmental environment. In such conditions, the state of economic security is one of the elements of the sustainable development of the Ukrainian economy. This is a necessary condition for the economic system of Ukraine as a whole, as well as for a separate enterprise. Economic security is also a key element in raising the level of competitiveness of economic entities and the country in the current conditions of unstable economic development of the world. The goal of investment security in Ukraine is to create a single mechanism, which constantly 


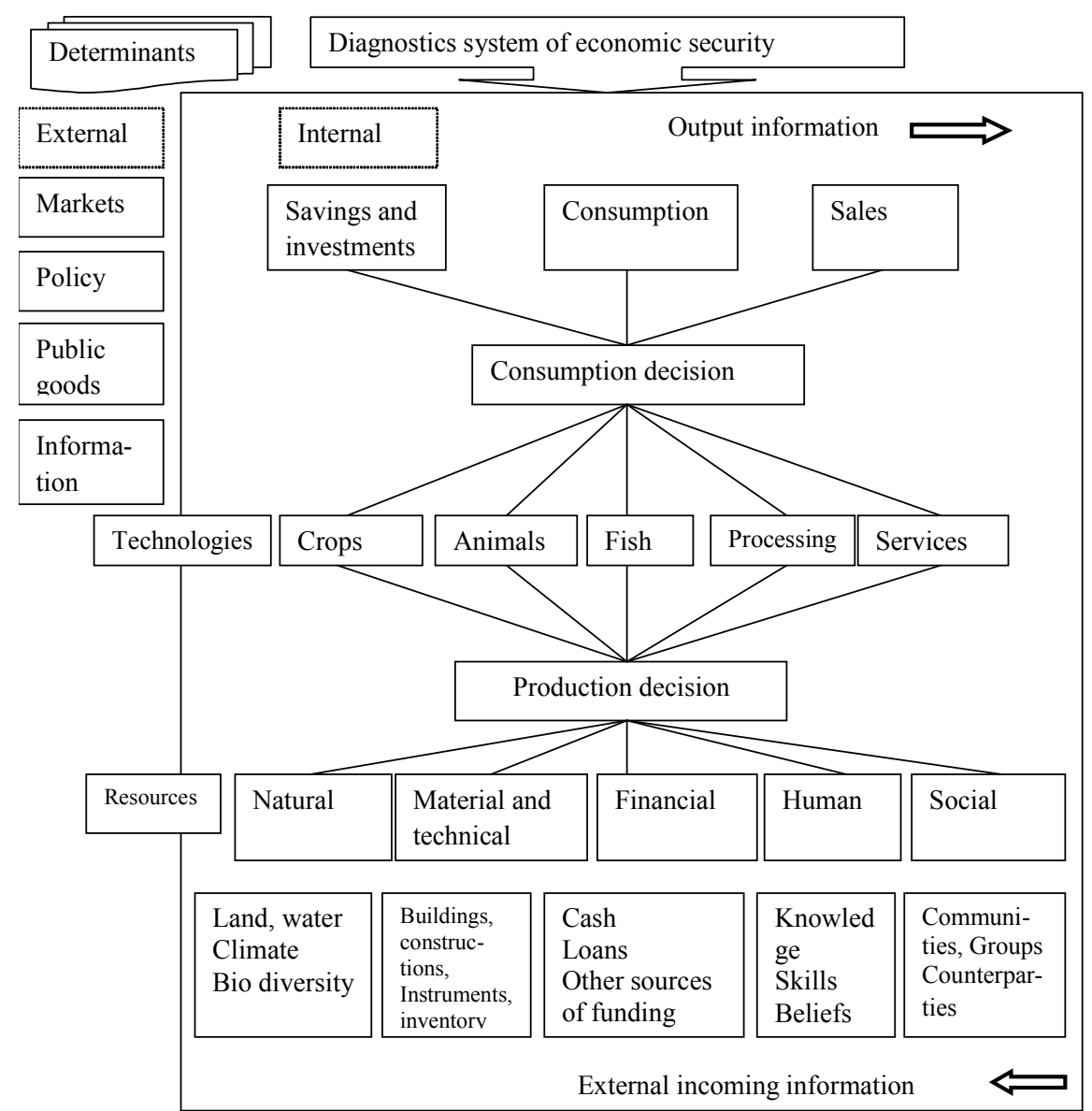

Fig. 1. Decision-making by agricultural enterprises related to the attraction of resources, production, consumption and investments in the system of diagnostics of economic security

attracts money, on the one hand, and, on the other hand, provides for the continuous selection, preparation and implementation of new investment projects. The Ukrainian government is interested both in protecting economic security and in securing the economic benefits associated with an open investment environment.

Ganna Blakyta, Natalia Guliaieva, Iryna Vavdijchyk, Olena Matusova and Anastasia Kasianova (2018) define the security of the investment environment as an integral part of the system of economic security. It indirectly characterizes the conditions and prospects for economic development, reflects the strategic aspect of getting immunity to real and potential, internal and external threats.

Ganna Blakyta, Olena Matusova, Halyna Lanovska and Victor Adamenko (2017) study the trends of the world economy, the nature and peculiarities of relations between economic entities, strategies of economic development of the government, and determine the preconditions for the formation of an entrepreneurial environment. According to such factors, the efficiency of entrepreneurial activity depends directly on the level of security of the existing business environment. The appropriate level of development and the security of entrepreneurship is an integral part of the market economy and it is in line with the important goal of state economic reforms - to create an effective competitive economy that provides a high quality of life for the population and is a key condition for economic and social security of the country. Effectiveness of state regulation of entrepreneurial activity forms the conditions necessary for activating entrepreneurship in the country. The role of economic security of entrepreneurship is also significant given the current trends in increasing the openness of the economy. Government measures to protect the economic interests of enterprises will ensure their sustainable functioning and development in the conditions of European integration of Ukraine.

\section{IDENTIFY PREVIOUSLY UNRESOLVED PART OF THE PROBLEM}

The available studies mainly focus on internal factors that determine the business security of an enterprise. After analyzing the results of scientific studies of foreign business security scientists from 
Table 1. Research parameters and special results

\begin{tabular}{|l|l|}
\hline \multicolumn{1}{|c|}{ The aim of the study } & \multicolumn{1}{c|}{ Results } \\
\hline $\begin{array}{l}\text { Building profit distribution rules } \\
\text { that encourage a network of } \\
\text { partners to handle innovation }\end{array}$ & $\begin{array}{l}\text { Three different rules for } \\
\text { distributing profits are proposed } \\
\text { based on theoretical analysis }\end{array}$ \\
\hline $\begin{array}{l}\text { Building rules for profit } \\
\text { distribution, which stimulate the } \\
\text { network of partners to a dynamic } \\
\text { reduction of costs and increase the } \\
\text { competitive position of the network }\end{array}$ & $\begin{array}{l}\text { It is necessary to comply with } \\
\text { the rule of profit distribution } \\
\text { and award the innovator also in } \\
\text { different competitive positions }\end{array}$ \\
\hline $\begin{array}{l}\text { The study of the applicability of the } \\
\text { proportional distribution of benefits } \\
\text { from patent licensing in the context } \\
\text { of technological standards }\end{array}$ & $\begin{array}{l}\text { Proportional distribution of } \\
\text { benefits is used with the } \\
\text { prospects of technology } \\
\text { development and market } \\
\text { growth }\end{array}$ \\
\hline $\begin{array}{l}\text { Construction of a multi-criteria } \\
\text { model of partner choice that meets } \\
\text { the requirements of } \\
\text { interdependence between them and } \\
\text { partner candidates }\end{array}$ & $\begin{array}{l}\text { New models for registration of } \\
\text { interdependencies of the } \\
\text { network in the choice of } \\
\text { partners }\end{array}$ \\
\hline
\end{tabular}

the point of view of innovation development, there is a need to consider a complex of external factors that affect the economic safety of enterprises and the business environment. In order to provide an assessment of the level of economic security of entrepreneurship, an innovative component of the polystructural process of diagnosing economic security is offered.

\section{THE PURPOSES FORMATION OF THE ARTICLE}

The purpose of the article is to identify the innovative component of the polystructural process of forming and diagnosing economic security of the enterprise.

\section{PRESENTING THE MAIN MATERIAL}

From a conceptual point of view, it is useful to distinguish between the analysis and diagnostics of the system of economic security of an individual enterprise, from the analysis of economic security of a set of enterprises with clear group characteristics or models. Each individual enterprise or set of enterprises has its own peculiarities that arise as a result of changes in resources and circumstances in the context of local institutions and policies. They turn into productive activities, as well as enterprise consumption and decisionmaking (Fig. 1).

Managers usually perceive their enterprises, whether small or small, as complex and risky "systems", and actively manage businesses to achieve their goals, including food security and livelihood. Each enterprise has diverse natural resources such as different types of land, water sources and access to shared resources in the context of climate and biodiversity, as well as human, social and financial capital. Generally, enterprises are interdependent and diverse, for example, agriculture, livestock, fisheries, hunting and gathering, as well as resource procurement, market analysis and production, product marketing. Work outside of the company is also an important and growing source of life for many business owners.

The functioning of any individual enterprise system is strongly influenced by the local external rural environment, including local institutions, land markets, labor and resources, as well as information communications. In fact, it is important to include the tight aspects of local institutions in the analysis of the farming system. Thus, the limits of the system of economic security of enterprises are determined by the boundaries of decision-making, for example, including decision-making and income streams related to non-agricultural work.

In this analysis, the system of economic security of a set of enterprises is defined as a combination of small and large enterprises, which, like a group, have similar patterns of life and consumption, as well as constraints and opportunities, and for which such development strategies and interventions would be appropriate. Often such systems have similar agroecological and market conditions.

Enterprises usually make their decisions to maximize profits. Profit is the result of incoming and outgoing cash flows, which, on the one hand, depend on the success of the market, and, for example, on operating costs and capital costs, on the other. Consequently, future cash flows determine the level of success, as long as the cost of time is recorded. However, an accurate estimate of future cash flows at the time of the decision is usually unrealistic; Uncertainty, for example, the development of the market, the decisions of competitors, as well as future costs, give rise to high uncertainty in future cash flows. 
The price is paid to subcontractor

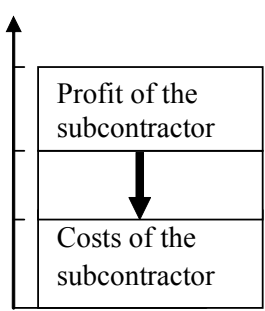

a) Increase the profit of the subcontractor

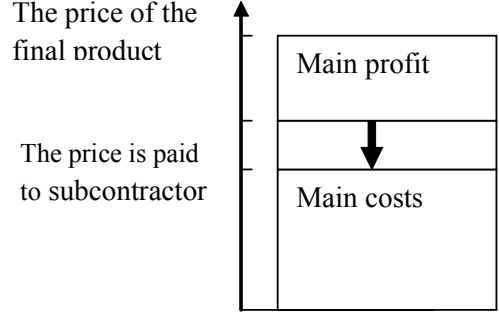

b) Increase the main profit

The price of the final product the price is paid to subcontractor

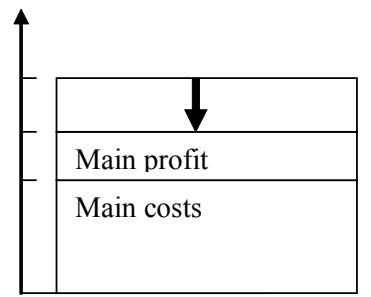

c) Reduce the price of the final product

Fig. 2. Three variants of profit distribution in assessing the economic security of the enterprise

In cases where it is practically impossible to estimate future cash flows with sufficient accuracy, other, more accurately measurable attributes or criteria that affect cash flows need to be determined. After that, evaluate the alternatives to executing the decision with respect to the attributes, thus trying to determine the most desirable alternative. Different multicriteria methods were used. In such cases, it is useful to identify pareto-efficient alternatives in which one criterion is improving and involves a compromise with another criterion. It should be noted that this demonstrates the connection between multicriteria analysis of solutions and the theory of games; the criteria correspond to the winnings of different players.

The outside world generates numerous exogenous uncertainties, which often provide realistic parameters that are solutions that must be taken. The formulation of decision-making cases, as optimization problems, is often useful. The advantages of such formulations are that there are numerous methods for solving the problem for different categories of optimization. Thus, most routine calculations can be computerized and provide an opportunity to focus on interpreting the results.

This study creates regulatory models for enterprises to make the best decisions in the network of values, when the goal is an efficient and structurally reliable cooperation. The models use theoretical game concepts for multilateral decision making, which involves both cooperation and competition. Moreover, the theory of transaction costs is particularly useful in the study of inter- organizational effectiveness. Analysis and optimization of decisions, in turn, are used in situations that best characterize the state of the company's economic security.

When securing economic security of the enterprise, the following principles are used:

Principle 1: There is no altruism in networks; enterprises seek to maximize their profits. Therefore, structurally stable value networks have incentives, pre-agreed rules for distributing profits, which direct the network to create global value.

Principle 2: A production network where there is a history of trust and cooperation is used as criteria for selecting partners. It is necessary to emphasize the importance of inter-organizational synergy in the choice of partners.

Principle 3: Intergovernmental factors affect the network's success. Thus, in addition to the organizational choice of partners, it is necessary to take into account the interdependence between the partner candidates. Examples include the history of cooperation, trust between enterprises and geographical distance.

The above postulates are related to the fact that the development of reliable networks of value requires: (1) employment, (2) the choice of synergistic configurations partners minimizing transaction costs.

This study contributes, firstly, to the analysis and development of profit distribution rules that can be used as incentives for innovation in value networks; and secondly, by constructing multi-criteria partner selection models that include interdependencies among the partner candidates. Table 1 lists the research parameters and results. 
Table 2. Synergy of three levels of diagnostics of economic safety of agricultural enterprises

\begin{tabular}{|l|l|l|}
\hline \multicolumn{1}{|c|}{$\begin{array}{c}\text { Level of } \\
\text { analysis }\end{array}$} & \multicolumn{1}{|c|}{$\begin{array}{c}\text { Post 1: Innovative incentives and } \\
\text { income participation }\end{array}$} & \multicolumn{1}{c|}{$\begin{array}{c}\text { Postulate 2: Choosing a } \\
\text { Synergistic Partner }\end{array}$} \\
\hline Enterprise & $\begin{array}{l}\text { A rational enterprise uses the } \\
\text { distribution mechanisms of its } \\
\text { networks and tries to restructure its } \\
\text { partnerships where other companies } \\
\text { can benefit without appropriate } \\
\text { contributions to the network }\end{array}$ & $\begin{array}{l}\text { Efficient businesses go beyond } \\
\text { their own partners. The partners' } \\
\text { partners and their interrelations } \\
\text { give a more holistic view of the } \\
\text { intentions of other enterprises }\end{array}$ \\
\hline Network & $\begin{array}{l}\text { A trusted network sets incentives } \\
\text { that encourage partners to contribute } \\
\text { to the network. The optimal } \\
\text { incentives for long-term } \\
\text { relationships are co-ordinated, } \\
\text { transparent, and take into account } \\
\text { the dynamics of the business } \\
\text { environment }\end{array}$ & $\begin{array}{l}\text { In addition to the competence of } \\
\text { the partners, the success of the } \\
\text { network depends on the } \\
\text { effectiveness of cooperation. } \\
\text { Hence, the optimal choice of } \\
\text { partners relates to the } \\
\text { organizational relationships } \\
\text { between the partner candidates }\end{array}$ \\
\hline $\begin{array}{l}\text { Innovative } \\
\text { system }\end{array}$ & $\begin{array}{l}\text { Transparent profit distribution rules } \\
\text { and system tools reduce the } \\
\text { company's cost of contracting and } \\
\text { litigation }\end{array}$ & $\begin{array}{l}\text { Communication with all is not } \\
\text { valuable. Thus, there are } \\
\text { incentives for synergy between } \\
\text { universities, research institutes } \\
\text { and companies as a space for } \\
\text { self-organization }\end{array}$ \\
\hline
\end{tabular}

Reliable structures for cost networks according to agreed profit distribution rules. Collaboration in value networks usually requires a kind of commitment or network contribution. Examples of such contributions are the reorganization of the workload, the openness of cost information and investment in technology development. However, according to Principle 1 , enterprises expect to return their contributions.

If the company estimates that the expected returns do not compensate for the contributions, then the defective "free ride" becomes the dominant alternative. The fear of low compensation is especially present in networks of values with young partnerships, low credibility and opportunism.

The network may reduce the uncertainty of the partners regarding compensation by the prior agreement of the rules for distributing profits. Thus, they develop and analyze rules for distributing profits, which, firstly, encourage network partners, and secondly, are practically feasible. The development of rules for the distribution of profits relies on the theory-game concept. As a result, not all rules for distributing profits are acceptable. The rules must be such that innovations are rewarded, and the opportunity for undeserved rewards is minimized. Thus, the responsible design of the rules for distributing profits in order to ensure the economic security of the enterprise takes into account the following considerations:

- Theoretically substantiated rules measure the contribution and reward the partners accordingly. In contrast, if the distribution of profits is based on costs plus profits, there is a risk that the network partners are showing higher costs than is appropriate. This risk is especially present when the partners are affiliated with several networks.
- Measurement of parameters should be practically feasible, so that the efforts made do not reduce the benefits of innovation. However, the pursuit of pragmatism cannot lead to the use of bad measures.

- Transparent and mutually agreed rules help strengthen trust among partners, which in the long run reduces transaction costs.

- Rules for distributing profits should take into account the dynamics of the network of values and the environment of the business environment. Thus, the distribution of profits cannot be regarded as a static problem with one task, but as an ongoing process throughout the life cycle of a network of values.

In fact, there are practically feasible rules that meet the requirements of the company's economic security. The rule of distribution of profits can be an incentive to reduce costs in networks with the main manufacturer and several subcontractors. Here, the profit to be shared is the amount of cost reduction, in which, in the case of the existence of three parties, among which the benefit is distributed: subcontractors, the main producer, and the customer, the client (Fig. 2).

Practically there are possible accounts for sharing profits for the competitive position of the network as follows. First, if the network is uncompetitive against its competitors, then a large part is the reduction of the price of the final product. Secondly, if the network already has a better price-cost position than its competitors, then network partners can distribute profits among themselves. Regardless of the competitive position, innovative subcontractors always receive the same shares, which exclude their chances of benefiting from reduced costs (Fig. 2).

In cases where the contribution is measurable, the practical rule is to share benefits in proportion 
to the contribution. The pro rata rule is used, for example, in joint ventures where funding is provided. Investment is a measure of contribution. It is being studied when a network of partners contributes to setting standards by investing in technology development. Here, the contribution is estimated as the number of standard patents accumulated by enterprises. The real options in the distribution of income must be taken into account, while the latter includes market decisions of enterprises in the study of the distribution of benefits.

In general, the more transparent the network of values, the easier it will be to build rules for the possible distribution of profits. In enterprise networks, revenue sharing options are a good way to become transparent.

Next, we will consider the synergetic configurations of the diagnostics of economic safety of the agricultural enterprise. Choosing the right partners can be crucial to the success of the network of values. Often the choice of a partner cannot be made solely on the basis of financial indicators, such as the assessment of cash flows, since the differences in the performance of partner partners cannot be measured in cash. On an example of an article, the least important were the monetary criteria, since the continuity of important customer activity depends on the successful completion of the project.

Therefore, partners are often selected on the basis of several criteria. There are numerous criteria according to which partners are usually selected. The most typical are quality, punctuality, learning opportunities, corporate image, financial stability and economic security. In addition to the second principle, the only use of specific criteria for partners, neglects the possible benefits of synergistic effects. Nevertheless, the benefits of synergies linked, for example, with the history of cooperation, trust between enterprises, geographical location, cultural compatibility, etc., can reduce transaction costs and promote openness and innovation in the network of values. Therefore, based on additional criteria, models are useful for decision making in the network at three levels. Initially, models help an individual company to optimize its participation in different networks. Second, the models support those who make decisions online, directing their partners to create a global value. Thirdly, the results give an idea to the managers at the level of the innovation system.

Valuable network models increase understanding of complex network connections and open the way for optimal design of network structures. However, formal optimization requires an assessment of model parameters, which in some cases may be very complex or too expensive. In such cases, the most important advantage of simulation is the conceptualization and increase of knowledge of the business environment.

In addition to parameter estimates, another source of inaccuracy stems from the limited ability of models to describe the real world. The modeling should balance the complexity of the model and the number of details, on the one hand, and the clarity and computing power, on the other. In any case, the responsible manager, firstly, focuses on the validity of the model; and secondly, the level of detail determines the use of the model - whether it is pure conceptualization, or also includes numerical calculations and optimization.

If the main purpose of the models is to support decision-making, it is worth noting a few issues. Firstly, the determination of the parameters should not be too complicated. Typically, there are business experts who are in demand for this work, and there are requirements in other activities. Secondly, the responsible use of numeric models does not seek a single optimal value, although models can contribute to consistent optimization. Instead, it is more reliable to identify a few good alternatives in which the economic security diagnosis can focus on further evaluation. Thirdly, the results of the models should pass a critical qualitative test, which opposes their practical experience.

Topology of the network affects the suitability of the models. In very large networks, computational fitness may restrict the use of combinatorial models. Moreover, heterogeneity within the network of partners complicates the modeling process, because it is necessary to model different partners.

First, the construction and implementation of the agreed rules for the distribution of profits reduces the uncertainty of the network partners regarding the profits on their contributions. As a result, increased transparency motivates network partners to contribute, which leads to greater potential for innovation. Secondly, accounting for interorganizational dependencies in the selection of partners helps to get a holistic view of possible network synergies. In contrast, these models of synergy are ignored only in the models of choice of partners, taking into account the results of the activities of individual enterprises. In any case, the value of the networks stems from the appropriate combination of competencies, as the respective partners have been identified, and the network structure is such that the partners have an incentive to contribute. If any of these conditions are violated, there is a high risk of inefficiency and threats to the economic security of enterprises. Similar implications for innovation policy; socially optimal innovative systems are rewarded and encouraged by risky research and development that is carried out 


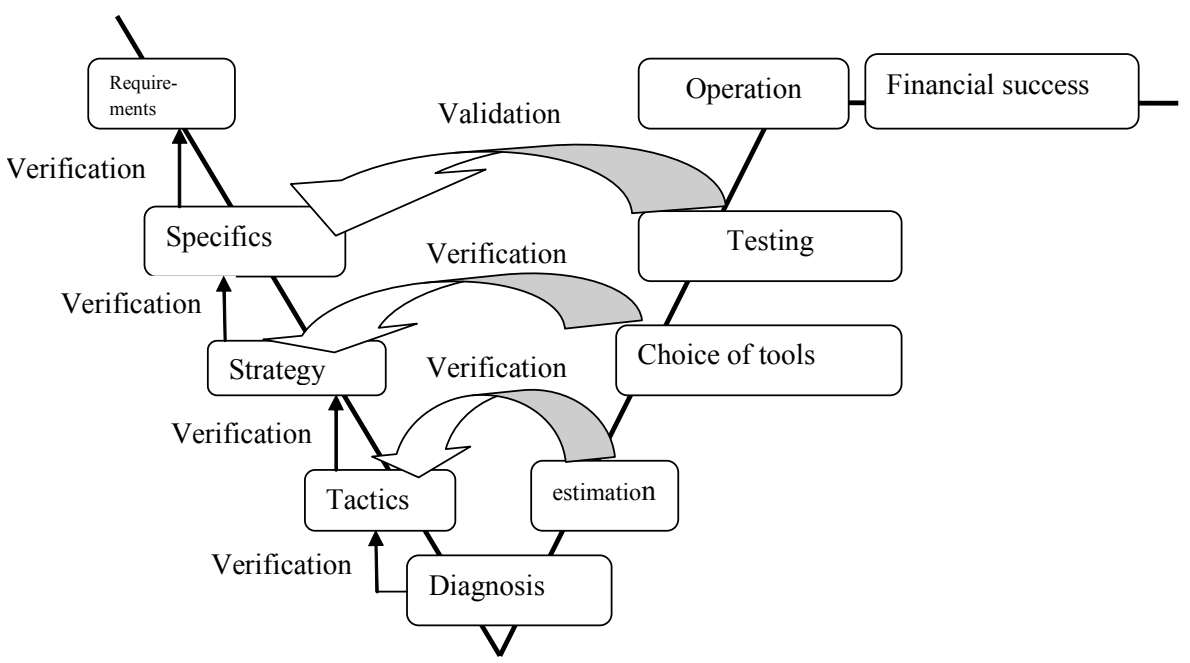

Fig. 3. V-model of diagnostics of economic security of agricultural enterprises

in collaboration between universities, research institutes and enterprises. However, the tools of the innovation system should emphasize selforganization instead of network configuration from the top down.

More research, development and globalization of networks require tools that prevent excessive increase in transaction costs and increase understanding of managers at enterprise level. As networks grow, they lose their effectiveness by increasing the number of network relationships. Moreover, combining additional competencies to meet the needs of clients requires a very broad knowledge; In large networks, it's dear to teach people such wide knowledge.

The company's economic security diagnosis is a system that is capable of performing its mission, even in the event of a failure of the control system. The catastrophic consequences of failures in financial and economic activity, suggest that there are shortcomings during the diagnosis and avoid their spread at the stage of the system, which is a critical task. Thus, V \& V activity in the relevant phases of the company's life cycle should be performed as soon as possible. In addition, the $\mathrm{V} \& \mathrm{~V}$ development process is more than $50 \%$ of total time and cost.

Thus, it is proposed to adopt methods and techniques for the $V \& \mathrm{~V}$ process in diagnosing the economic safety of an agricultural enterprise, since they are able to reduce and optimize resources when carrying out a diagnosis of economic security. Testing can show the presence, and not the absence of errors, $\mathrm{V} \& \mathrm{~V}$ activity is the best way to solve the problem of a critical situation in an enterprise.

Further research will focus on a thorough overview of the $V \& V$ process, especially taking into account the practice applied in the context of financial and economic activity of agricultural enterprises.
$V \& V$ concept of diagnostics of economic safety of an agricultural enterprise. Consider the importance of $V \& V$ for the diagnosis of economic security of agricultural enterprises. The concepts of verification and validation (V\&V) are usually considered together if there are corresponding differences between them. In particular, the main difference is related to the purpose that governs these two phases. Two questions are proposed which now perfectly specify the difference between verification and validation:

- Verification answers the question "Is the product manufactured / manufactured properly?", which means that the verification relates to the compliance of the system of economic security with the requirements;

- Validation instead relates to the question "Is the product manufactured / manufactured?", this means verification to determine whether the system works correctly, taking into account its specifications (or in other words, user expectations).

With respect to the existing and consolidated approaches contained in the literature, one can divide V \& V into two macro categories: static and dynamic. Static approaches focus on inspections and reviews of artifacts developed during the development of the system and their precondition that the study system is not put into operation. Static approaches can reveal shortcomings in the design of the system and in the general defects of financial and economic activity of the enterprise. In addition, the cost of static approaches is low. The main limitation of static approaches is that they cannot detect defects that may occur when system components interact, such as time problems, performance problems, or even poor management. This requires the use of dynamic approaches and specific testing. Dynamic approaches, in fact, can prove that the system behaves as expected or that it fulfills its functional requirements 
Testing is, in fact, one of the most important tasks of $V \& V$ and can be carried out at various stages of the system's life cycle. Identifying systemic threats as early as possible and bringing them to acceptable levels is the best way to address the issue of economic security. However, well-tested techniques adopted during the life cycle of the system are not able to cope with the complexity of modern systems and technologies. Inadequacy reflects the fact that the adoption of these methods does not guarantee the proper level of the system of economic security of the enterprise.

The system of economic security concerns the identification of hazards, the definition of their causes, the development of appropriate countermeasures, and can be used to check the effectiveness of strategies.

V-model of diagnostics of economic security of agricultural enterprises. The stages of development of such a model are shown in Fig. 3 and detailed below. A typical structure based on "V" arranges the phases of development in the complexity with the most complex element from above and the least complex element from below. This puts a strategy next to the choice of tools in the sense that the adoption of diagnostics of economic security is inextricably linked with development activities.

In the life cycle, there are several stages, starting with the concept of system deployment, clarification of input data, requirements, results and methods for checking each phase. For brevity, these phases can be divided into four macro-activities.

The purpose of this stage (estimation of V model of diagnostics of economic security of an agricultural enterprise) is to develop a level of understanding of the system of diagnostics of economic security sufficient to ensure that all subsequent life-cycle tasks are carried out satisfactorily. In this phase, the profile of the mission, the boundaries, conditions of application, which affect the characteristics of the system are determined. Also, this phase defines the general system requirements, as well as the general criteria for demonstration and decision making for the system.

Tactics: during this phase, requirements are distributed among all subsystems, specific criteria for decision-making at the subsystem level are determined. Thus, appropriate requirements are created and compliance with them is demonstrated through the use of appropriate formal models.

Testing: after the implementation of the subsystems, the objectives of this phase are to confirm that the combined combination of subsystems, components and external risk mitigation measures meets the system requirements; In this phase, specific characteristics are collected to assess compliance with the requirements of the whole system, and therefore, the system adopted by the company's economic security diagnostics system.

Operation: the purpose of this phase is the operation of the enterprise under the optimum conditions (within the limits of the specified limits), to maintain a combined combination of subsystems, components and external risk mitigation measures that ensure compliance with the system requirements; keep the system's performance based on monitoring the state of the company's economic security.

Thus, the innovative component of the company's economic security is a system of enterprise security measures, designed to: 1) ensure the widespread use of innovative innovations both in sales and production, and in other stages; 2 ) create an innovation-friendly climate both in the production process and in protecting the enterprise from internal and external threats.

\section{CONCLUSIONS AND PERSPECTIVES OF FURTHER RESEARCH}

The scientific novelty of this article is to improve the diagnosis of economic security of the enterprise, namely the allocation of the innovative component into a separate component of economic security. Methods of improving the diagnosis of economic security are proposed. In further research, there is a need to develop a methodology for assessing the level of innovative component of economic security. This study examines some relevant research trends in the context of $\mathrm{V} \& \mathrm{~V}$, discusses critical elements of economic security.

Several ways are suggested for further research. Firstly, since the partnership involves a risk of inefficiency, the issue of optimality of network management in a competitive environment is relevant, and when it is profitable to seek partnership. Answers to these questions require more research in terms of empirical and theoretical studies. Thirdly, in knowledge-based networks, the competences of different partners are intangible, and it can be more efficient to transfer knowledge rather than money. Additional research is needed to study the preconditions for the transfer of intangible assets in the network. Networks that offer services require methods for assessing the value of services and further distribute the cost of services between clients and network partners.

\section{$\Lambda$ ітература:}

1. Забезпечення фінансово-економічної безпеки підприємництва: навчальний посібник/ Г.В. Соломіна. - Аніпро: Аніпропетровський 
державний університет внутрішніх справ, 2018. $-234 \mathrm{c}$.

2. Фролова Г. Технологія прийняття управлінських рішень в умовах ризику та невизначеності / Г. Фролова // Вісник ТАЕУ. - 2016. № 1. - C. $87-93$.

3. Dzumadilova S., Sailaubekov N., \& Kunanbayeva D. (2017). Company's financial state forecasting: methods and approaches. Investment Management and Financial Innovations, 14 (3), 93-101. https://doi.org/10.21511/ imfi.14(3).2017.09

4. Frank, S. (2015). Foreign direct investment and sustainable development in the European Union. Retrieved from https://hrcak.srce.hr/file/ 223265

5. Ganna Blakyta, Nataliia Guliaieva, Iryna Vavdijchyk, Olena Matusova and Anastasia Kasianova (2018). Evaluation of investment environment security in Ukraine. Investment Management and Financial Innovations, 15 (4), 320-331. doi:10.21511/imfi.15(4).2018.26

6. Ganna Blakyta, Olena Matusova, Halyna Lanovska and Victor Adamenko (2017). Integral assessment of business environment security. Problems and Perspectives in Management, 15 (4), 280-292. doi:10.21511/ppm.15(4-1).2017.12

7. Nataliya Pedchenko, Victoria Strilec, Galina M. Kolisnyk, Mariia V. Dykha and Serhiy Frolov (2018). Business angels as an alternative to financial support at the early stages of small businesses' life cycle. Investment Management and Financial Innovations, 15(1), 166-179. doi:10.21511/ imfi.15(1).2018.15

8. Mamychev et al. (2016), Economic security and organizational culture: Theoretical approaches and categorical relationship. International Review of Management and Marketing, 6 (S1), $153-158$.

9. Silver L., Berggren B., \& Fili A. (2016). The role of crowdfunding in entrepreneurial ventures: an analysis of recent trends in Sweden. Investment Management and Financial Innovations (open access ), 13(1-1). https://doi. org/10.21511/ imfi.13(1-1).2016.09

10. Wehrle F. B., \& Pohl J. (2016). Investment Policies Related to National Security: A Survey of Country Practices. Paris: OECD Publishing.

\section{References:}

1. Solomina, G.V. (2018), Ensuring financial and economic security of entrepreneurship: a manual, [Zabezpechennya finansovo - ekonomichnoyi bezpeky pidpryyemnytstva], Dnipro- petrovsk State University of Internal Affairs, Dnipro, Ukraine.

2. Frolova, G. (2016), "Tekhnolohiya pryynyattya upravlinskykh rishen $\mathrm{v}$ umovakh ryzyku ta nevyznachenosti", Bulletin of the TEDU, vol.1, pp. 87-93.

3. Dzumadilova, S. Sailaubekov, N. and Kunanbayeva D. (2017), "Company's financial state forecasting: methods and approaches", Investment Management and Financial Innovations, vol. 14 (3), pp. 93-101, available at: https://doi.org/ 10.21511/ imfi.14(3).2017.09 (Accessed 25 Feb 2019).

4. Frank, S. (2015), "Foreign direct investment and sustainable development in the European Union", available at: https://hrcak.srce.hr/file/ 223265 (Accessed 25 Feb 2019).

5. Blakyta, G. Guliaieva, N. Vavdijchyk, I. Matusova, O. and Kasianova, A. (2018), "Evaluation of investment environment security in Ukraine", Investment Management and Financial Innovations, vol. 15(4), pp. 320-331, available at: doi:10.21511/imfi.15(4).2018.26 (Accessed 25 Feb 2019).

6. Blakyta, G. Matusova, O. Lanovska, H. and Adamenko, V. (2017), "Integral assessment of business environment security", Problems and Perspectives in Management, vol. 15(4), pp. 280-292, available at: doi:10.21511/ppm.15(4-1). 2017.12 (Accessed 25 Feb 2019).

7. Pedchenko, N. Strilec, V. Kolisnyk, G. M. Dykha, M. V. and Frolov, S. (2018), "Business angels as an alternative to financial support at the early stages of small businesses' life cycle", Investment Management and Financial Innovations, vol. 15(1), pp. 166-179, available at: doi:10.21511/imfi.15(1).2018.15 (Accessed 25 Feb 2019).

8. Mamychev, et al. (2016), "Economic security and organizational culture: Theoretical approaches and categorical relationship", International Review of Management and Marketing, vol. 6(S1), pp. 153-158.

9. Silver, L. Berggren, B. and Fili, A. (2016), "The role of crowdfunding in entrepreneurial ventures: an analysis of recent trends in Sweden", Investment Management and Financial Innovations (open access), vol. 13(1-1), available at: https://doi.org/10.21511/imfi.13(1-1).2016.09 (Accessed 25 Feb 2019).

10. Wehrle, F. B. and Pohl, J. (2016), Investment Policies Related to National Security: A Survey of Country Practices, OECD Publishing, Paris, France.

Стаття надійшла до редакиї̈ 07.03.2019 p. 